\title{
No Association Between MTHFR Gene C677T/A1298C Polymorphisms, Serum Folate, Vitamin B12, Homocysteine Levels, and Prostate Cancer in an Algerian Population.
}

\section{Rima Mouhoub-Terrab}

Université des Sciences et de la Technologie Houari Boumediene: Universite des Sciences et de la Technologie Houari Boumediene

Abdel Aziz Chibane

Universite d'Alger Faculte des Sciences Medicales

Malika KHELIL ( $\square$ malikakhelil@hotmail.fr)

Universite des Sciences et de la Technologie Houari Boumediene https://orcid.org/0000-0002-47564407

\section{Research Article}

Keywords: Prostate cancer, Methylenetetrahydrofolatereductase, Genetic polymorphism, Folate, Vitamin B12, Homocysteine

Posted Date: March 2nd, 2022

DOI: https://doi.org/10.21203/rs.3.rs-1373580/v1

License: (c) (i) This work is licensed under a Creative Commons Attribution 4.0 International License. Read Full License 


\section{Abstract}

Background Methylenetetrahydrofolatereductase (MTHFR) enzyme plays a crucial role in the metabolism of folate and homocysteine, which are necessary for DNA methylation and nucleotide synthesis. Genetic polymorphisms that decrease MTHFR activity are implicated in several diseases as well as diverse malignancies including prostate cancer. The objective of this study was to evaluate an eventual association between MTHFR polymorphisms and prostate cancer within an Algerian population, taking into consideration serum levels of folate, vitamin B12, and homocysteine.

Methods and results A total of 106 men with newly diagnosed prostate cancer and 125 healthy controls were examined for MTHFR C677T and A1298C polymorphisms using PCR/RFLP and Real-Time PCR TaqMan ${ }^{\circledR}$ respectively. Serum levels of folate, total homocysteine, and vitamin B12 were measured using an automatic biochemistry analyzer.Our study showed no significant difference in genotype frequency of A1298C and C677T in patients compared to the control groups. As for serum levels of folate, total homocysteine, and vitamin B12, there were not associated with prostate cancer (P凶0.05). However, age and family history increased susceptibility to the disease $(O R=1.178, P=0.00$ and $O R=10.03, P=0.007$, respectively).

Conclusion Our results suggest that MTHFR C677T and A1298C as folate, total homocysteine, and vitamine B12 do not contribute to the risk of prostate cancer. On the other hand, age and family history are risk factors in an Algerian population. Therefore, further studies with a larger sample size are needed for the confirmation of our finding.

\section{Introduction}

Prostate cancer $(\mathrm{PCa})$ is one of the most important diagnosed neoplasmand is the fifth cause of cancerrelated death in men around the world. According to GLOBOCAN 2020 database, 1.4 million new cases and 375,000 deaths from prostate cancer were estimated in 2020, with the highest rates are in developed countries [1]. In Algeria, prostate canceris the second most frequent cancer affecting men (17.0 per $100,000)$ and the fourth leading cancer-caused mortality $(6.8$ per 100,000$)$ [1].

Prostate cancer is a complex illness, in which the etiology revolves around the interaction between genetic and environmental factors. The most well-known risk factorsinclude age, family history of PCa, and ethnicity. Additionally, diet, androgen stimulation and smoking have been considered secondary risk factors [2]. A recent study has supported the role ofmolecular alterations and DNA polymorphisms in the development and progression of PCa [3].

Methylenetetrahydrofolatereductase (MTHFR) is an important regulatory enzyme in the folate and homocysteinemetabolic pathways. It catalyzes the irreversible conversion of 5,10-

methylenetetrahydrofolate (5,10-methylene THF) to 5- methylenetetrahydrofolate(5-methyl-THF), which is the predominant circulatory form of folate and provides one-carbon group for the remethylation of homocysteine to methionine, a reaction for which vitamin B12 is a co-enzyme [4]. Methionine is 
considered as the precursor of S-adenosylmethionine (SAM) and the universal methyl donor in biological processes, including the methylation of proteins and DNA [5].Therefore, MTHFR plays an essential role in dTMP production and biosynthesis, repair, and maintenance of DNA stability [6].

The human MTHFR gene is situated in chromosome 1 (1p36.3), it is composed of 11 exons and encodes a protein of 656 amino acids.There are two commonly allelic variant of MTHFR gene, they have been described as the following: C677Tand A1298C. These MTHFR polymorphisms have been associated with decreased MTHFR activity, which lead to an increased plasma homocysteine level and a reduced plasma folate concentration. The MTHFR C677T is located at exon 4 leading to amino acid substitution (Ala $222 \mathrm{Val}$ ).This substitution causes a thermolabile transformation of the enzyme from 35 to $65 \%$ activity reduction [4]. The second variant $\mathrm{A} 1298 \mathrm{C}$ is located at exon 7, results in a glutamate-to-valine substitution at codon 429 and affects enzymefunction to a lesser degree. Nevertheless,the association with C677T polymorphism has a more effect on the decrease of MTHFR enzyme activity [7]. It might be estimated that MTHFR polymorphisms and the consequent decrease in enzyme function can produce genomic instability and activation of oncogenes by DNA hypomethylation or hypermethylation, causing cancerization and affecting the progression of malignant tumors [6] .

Previous studies have been reported that MTHFR gene polymorphism is known to be an increased risk of prostate cancer. Such results remained inconsistent and controversial [8-11]. Therefore, the aims of this study are to investigate for the first time in the North - Center of Algeria, the genetic polymorphisms of MTHFR, as well as their relationship with serum total homocysteine (tHcy), folate, vitamin B12 levels and environmental factorson the risk of PCa.

\section{Materials And Methods}

\section{Subjects}

This study consisted of 257 histologically confirmed PCapatients and 125 controls. All participants were diagnosed by physicians in the Department of Urology in Mustapha Bacha University Hospital, Algiers, Algeria, from December 2013 to August 2016. Among all patients, 151 (58.75\%) were eliminated due to using hormonal therapy, radiotherapy, or chemotherapy. The cohort of the investigation consisted of 106 patients with a median age at diagnosis was $67.98 \pm 6.31$ years. The risk categories are defined on the basis of cancer stage, Gleason score, and serum prostate-specific antigen (PSA) at diagnosis.

The control group includes volunteer healthy men with an average age of $61.06 \pm 6.60$ years, living in the same geographical area and without a prior history of cancer or pre-cancerous lesions. Such groups have undergone a digital rectal examination (DRE), serologicalPSA $(<4 \mathrm{ng} / \mathrm{ml})$ and radiological exams to exclude the possibility of prostate hyperplasia or prostate carcinoma.

All men who participated in the data give their informed consent and the local ethical committee approved this study. 


\section{Blood sampling and biochemical analysis}

Blood samples were collected from fasting participants using tubes without an anticoagulantand centrifuged at $2000 \mathrm{rpm}$ for 20 minutes at $4^{\circ} \mathrm{C}$. The serum was separated, aliquoted and stored at $-80^{\circ} \mathrm{C}$ until analysis. Biochemical assays on the serum were measured at the Department of Biochemistry in the Central Hospital of Army, Algiers. Serum folate and vitamin B12 concentrations were analyzed by competitive binding assays using electro-chemiluminescent detection (Elecsys 2010, Hitachi, Roche or COBASe401). The serum total homocysteine (tHcy) was measured by automated (ARCHITECT isystemimmunoassay, Abbott Laboratories)fluorescence polarization immunoassay.

\section{DNA extraction and genotyping}

Blood samples were collected in EDTA tubes, and genomic DNA was isolatedfrom peripheral blood via salting out method(Miller et al., 1988). The quantity and purity ofDNAwere checked by Nano spectrophotometer and agarose gel electrophoresis respectively.

Genotyping for MTHFR C677T(Rs1801133) was performed using polymerase chain reaction-restriction fragment length polymorphism (PCR-RFLP)procedure [4] .Genomic DNA (50-100 ng) was amplified in a $30 \mu \mathrm{l}$ PCR reactionmixture containing1X-taq DNA polymerase buffer, $1.5 \mathrm{mM} \mathrm{MgCl} 2,0.2 \mathrm{mMdNTPs}, 0.4 \mu \mathrm{M}$ of forwardprimer:5-TTTGAGGCTGACCTGAAGCACTTGAAGGAG-3, $0.4 \mu \mathrm{M}$ of reverse primer: 5GAGTGGTAGCCCTGGATGGGAAAGATCCCG-3 and $1 \mathrm{U}$ of Taq polymerase (PromegaMadison, WI USA). The PCR protocolwasas follows: initial denaturation $\left(94^{\circ} \mathrm{C}\right.$ for $\left.5 \mathrm{~min}\right)$; followed by $35 \mathrm{cycles}\left(94^{\circ} \mathrm{C}\right.$ for $30 \mathrm{~s}$, $68^{\circ} \mathrm{C}$ for $30 \mathrm{~s}, 72^{\circ} \mathrm{C}$ for $30 \mathrm{~s}$ ) and final extension at $72^{\circ} \mathrm{C}$ for $7 \mathrm{~min}$. The PCR products were thendigested at $37^{\circ} \mathrm{C}$ overnight with5U of Hinfl restriction enzyme (PromegaMadison, WI USA). The digestion products were obtained by electrophoresis on $2 \%$ agarose gel contained ethidium bromide and visualized under ultra - violet transilluminator.

The genotype for MTHFR A1298C (Rs1801131) was generated using the TaqMan probe real-time PCR method (7500 Fast Real-Time PCR System, Applied Biosystems, USA) with commercially available assays (IDs: C_850486_20; Life Technologies, USA). The10 $\mu$ reaction mixtureincluded5 $\mu$ l of TaqManGTXpress Master Mix (Life Technologies), 10 ng of DNA and $0.5 \mu \mathrm{l}$ of each primer and probe. The temperature profile consisted of initial denaturation at $95^{\circ} \mathrm{C}$ for $10 \mathrm{~min}$, followed by 40 cycles of two-step PCR (denaturation $95^{\circ} \mathrm{C}$ for $15 \mathrm{~s}$, annealing and elongation $60^{\circ} \mathrm{C}$ for $1 \mathrm{~min}$ ). The respective FAM and VIC fluorescence dyes on the probes were used for the wild type (A allele) and the mutant type ( $\mathrm{C}$ allele) to determine the sample genotype.

\section{Statistical analysis}

Statistical analyses were performed using SPSS version 20 (SPSS Science, Chicago, IL). An unconditional logistic regression model was carried out to indicate the effect of MTHFR gene polymorphism and othervariables onPCa risk. The results expressed as odds ratio (OR) and corresponding $95 \%$ confidence intervals (Cls). The analysis of the multivariate logistic regression was performed to calculate the best independent predictors of PCa for variables that have $p \llbracket 0.25$ in the 
univariate model. The Hardy-Weinberg equilibrium was used by chi-square $\left(\chi^{2}\right)$ test for genotype distribution. Differences were considered statistically significant when the $p$-value was less than 0.05 .

\section{Results}

\section{Characteristics of the study population.}

The distributions of the selected demographic, lifestyle habits and clinical characteristics of $106 \mathrm{PCa}$ patients and 125 controls are summarized in Table 1 . There was a significant difference between PCapatients and controls regarding age $(\mathrm{OR}=1.11, P=0.00)$, and family history $(\mathrm{OR}=2.53, P=$ $0.009)$. However, there was no statistically significant difference in the following indexes: Marital status $(P=0.99)$, residency $(\mathrm{OR}=1.08, P=0.821)$, occupational activity $(\mathrm{OR}=1.28, P=0.36)$ and tobacco $(\mathrm{OR}=$ 1.001, $P=0.996)$. 
Table 1

Demographic, clinical characteristics, lifestyle habit and biochemical analyses of the study subjects.

\begin{tabular}{|c|c|c|c|}
\hline Characteristics & $\begin{array}{l}\text { PCa patients } \\
(n=106)\end{array}$ & $\begin{array}{l}\text { Controls } \\
(n=125)\end{array}$ & $P$ value \\
\hline
\end{tabular}

Age at recruitment

$67.98 \pm 6.31$

$61.06 \pm 6.60$

0.00

1.11

(years \pm SD)

$(1.072-1.156)$

Marital status $(n, \%)$

$\begin{array}{llll}\text { Married } & 102(96.22) & 124(99.2) & 0.99 \\ \text { Single } & 04(3.77) & 01(0.8) & \end{array}$

Residency $(n, \%)$

Urban

$90(84.1)$

105 (84)

0.821

1.08

Rural

17 (15.9)

$21(16)$

(0.533-2.208)

Occupational activity $(n, \%)$

Manual labor

69 (64.4)

78 (62.4)

0.36

1.28

Office job

36 (35.6)

47 (37.6)

$(0.742-2.23)$

$\operatorname{Tobacco}(n, \%)$

Use tobacco

$75(70.45)$

78 (74.8)

0.996

1.001

(0.673-1.490)

Family history of PCa (\%) $\quad 20.2$

13.4

$0.009 \quad 2.532$

(1.262-5.079)

Biochemistry (Mean \pm SD)

Folic acid (ng Ml-1)

$12.57 \pm 22.90$

$9.26 \pm 5.23$

0.472

1.014

(0.977-1.051)

Vitamin B12 (pg mL $\left.{ }^{-1}\right)$

$295.44 \pm 104.71$

$362.74 \pm 195.71$

0.178

0.997

Homocysteine $\left(\mu \mathrm{mol} \mathrm{L}^{-1}\right)$

$10.10 \pm 3.19$

$12.34 \pm 8.27$

0.466

(0.993-1.001)

$19.53 \pm 17.69$

$3.72 \pm 2.77$

0.00

Total PSA (ng mL ${ }^{-1}$ )

Univariate odds ratio of prostate cancer risk using unconditional logistic regression analysis. Adjusted OR .SD: Standard deviation. PCa: Prostate cancer.PSA: Prostate-specific antigen. OR: Odds ratio refers to PCa. Cl:Confidence intervals. $P \otimes 0.05$ statistically significant. 


\begin{tabular}{|lll|}
\hline Characteristics & $\begin{array}{l}\text { PCa patients } \\
(n=106)\end{array}$ & $\begin{array}{c}\text { Controls } \\
(n=125)\end{array}$
\end{tabular}

The analysis of biochemical parameters showed that a total PSA value was significantly higher in PCa group $(P=0.000)$. Moreover, we noted no association between serum thcy $(\mathrm{OR}=0.975, P=0.466)$, folate $(\mathrm{OR}=1.014, P=0.472)$ and vitamin $\mathrm{B} 12(\mathrm{OR}=0.997, P=0.178$,$) levels and prostate cancer.$

\section{Genotype frequencies of MTHFR and haplotypes analysis.}

The distributions of the MTHFR gene polymorphisms were in Hardy-Weinberg equilibrium in both groups $P \otimes 0.05$. The investigation of the relationship between C677T and A1298C MTHFR polymorphism and PCawasperformed Univariate analyses in Table 2. 
Table 2

Frequency distribution of the MTHFR C677T, A1298C alleles, genotype and combined genotypes and their relation with $\mathrm{PCa}$.

\begin{tabular}{|c|c|c|c|c|}
\hline Polymorphism & PCan (\%) & Controlsn (\%) & $P$ value & OR $(95 \% \mathrm{Cl})$ \\
\hline MTHFR C677Т & $n=106$ & $n=125$ & & \\
\hline $\mathrm{CC}$ & $50(47.16)$ & $53(44)$ & 0.42 & $1.23(0.733-2.081)$ \\
\hline CT & $41(38.67)$ & $56(42.4)$ & 0.30 & $0.75(0.447-1.28)$ \\
\hline TT & 15 (14.15) & $16(13.6)$ & 0.90 & $1.04(0.486-2.268)$ \\
\hline C allele & $141(66.51)$ & $162(64.8)$ & 0.91 & 1.06 \\
\hline T allele & 71 (33.49) & $88(35.2)$ & 0.87 & 0.97 \\
\hline MTHFR A1298C & $n=105$ & $n=106$ & & \\
\hline AA & $62(59.0)$ & $67(63.2)$ & 1 & $0.83(0.475-1.445)$ \\
\hline$A C$ & $38(36.2)$ & $34(32.1)$ & 0.56 & $1.18(0.669-2.095)$ \\
\hline CC & $05(4.8)$ & $05(4.7)$ & 0.51 & $1(0.281-3.56)$ \\
\hline A allele & $48(22.85)$ & $168(79.24)$ & 0.67 & 1.1 \\
\hline C allele & $162(77.14)$ & $44(20.75)$ & 0.85 & 0.97 \\
\hline C677T/A1298C & $n=105$ & $n=105$ & & \\
\hline CC/AA & $21(20)$ & 28 (27.67) & 0.38 & 0.75 \\
\hline $\mathrm{CC} / \mathrm{AC}$ & $23(21.9)$ & $18(17.14)$ & 0.46 & 1.29 \\
\hline $\mathrm{CC} / \mathrm{CC}$ & $05(4.76)$ & $03(2.85)$ & 0.48 & 1.69 \\
\hline CT/AA & $28(27.67)$ & $29(27.61)$ & 0.93 & 0.97 \\
\hline $\mathrm{CT} / \mathrm{AC}$ & $13(8.66)$ & 15 (14.28) & 0.74 & 0.87 \\
\hline $\mathrm{CT} / \mathrm{CC}$ & 0 & $01(0.95)$ & - & - \\
\hline TT/AA & $13(13.38)$ & $10(9.52)$ & 0.54 & 1.31 \\
\hline TT/AC & $02(1.90)$ & $01(0.95)$ & 0.56 & 2.02 \\
\hline TT/CC & 0 & $01(0.95)$ & - & - \\
\hline \multicolumn{5}{|c|}{ Univariate odds ratio of prostate cancer risk using unconditional logistic regression analysis. } \\
\hline
\end{tabular}


According to these results, genotype and allele frequencies did not show any significant differences between patients and controls $(P>0.05)$. The combined effect of the two polymorphisms, 677CT/1298AC genotype also showed no association with the risk of $\mathrm{PCa}$.

\section{Multivariate Logistic Regression}

The results of multiple logistic regression analyses were chosen to find the best independent predictors; in this analysis, only age $(\mathrm{OR}=1.178, P=0.00)$ and family history $(\mathrm{OR}=10.03, P=0.007)$ appear as independent risk factors for prostate cancer development (Table 3).

Table 3

Results of multivariate adjusted analysis between prostate cancer cases and controls according to MTHFR genotypes, biochemistry analysis and demographic parameters.

\begin{tabular}{|llll|}
\hline \multicolumn{1}{|c|}{$P$ value } & OR & $95 \% \mathrm{Cl}$ \\
\hline Age & 0.00 & 1.178 & $1.083-1.282$ \\
\hline Family history & 0.007 & 10.03 & $1.88-53.62$ \\
\hline $\begin{array}{l}\text { Adjusted OR by age, residency, occupational activity, tobacco status, family history, serum folate, } \\
\text { vitamin B12, homocysteine and } \text { MTHFR genotypes refer to risk of prostate cancer. }\end{array}$ \\
\hline OR, odds ratio refers to PCa; Cl, confidence intervals. \\
\hline$P \llbracket 0.05$ Statistically significant \\
\hline
\end{tabular}

\section{Discussion}

MTHFR enzyme plays a pivotal role in intracellular folate and homocysteine metabolism, which are fundamental for DNA methylation, synthesis, and genomic integrity [13]. Imbalance in the circulating concentrations of folate,homocysteine and vitamin B12 may cause DNA damage leading to genetic instability which is related to the occurrence of several cancers including prostate cancer [14-16]. In fact, it was reported that folate deficiencywill induce in $\mathrm{CpG}$ island hypermethylation and uracil misincorporation into DNA strands, resulting in genetic and epigenetic instability observed in murine PCa models. However, a high level of serum folate andhomocysteine increases prostate cancer progression. This conflicting results may reflect the potential dualistic role of folate in prostate carcinogenesis [15]. Moreover, high serum level of vitamin B12 and homocysteinehas been associatedwithprostate cancer risk $[15,17]$. Unlike previous findings, in our study, we found no relationship between these vitamins, homocysteineand the risk of prostate cancer development. Our results were consistent with the findings of Weinstein et al [18] andBeilby et a [19].

As for the relationship between MTHFR polymorphisms and prostate cancer, the results showed no significant differences in our population. The results were consistent with several meta-analyses which have reported that $\mathrm{C} 677 \mathrm{~T}$ and $\mathrm{A} 1298 \mathrm{C}$ polymorphisms were not associated with prostate cancer in Caucasian, mixed, and Asian populations [11, 20-22]. However, some published data showed a positive 
association between the MTHFR C667T polymorphism and PCa development [10, 23]. Moreover, it was reported that the genotype 677 TT exerts a protective effect on prostate cancer risk in the Spanish and Asian populations [24, 25]. As well as, Cicek et al.[26] suggested that $677 \mathrm{~T}$ and $1298 \mathrm{~A}$ may be associated with the reduction of prostate cancer progression. These conflicting results may be due to the methods of control selection, their dietary differences, geographical regions, ethnic origins, as well as their exposure to diverse environmental risk factors.

Tobacco isidentifiedas an environmental risk factor for cancercausing $30 \%$ of all human cancers including PCa [27]. Two several biologicalmechanisms were proposed to promote carcinogenesis in the prostate: First of all, tobacco contains a multiple carcinogenic compounds, which can indirectly induce PCa through their interaction with androgen receptors [28]. Secondly, it was reported that men smokers have elevated levels of circulating testosterone, androstenedione, and DHT [29]. Nevertheless; other studies have not supported the link between tobacco smoking and prostate cance [30]. Similarly, our results showed that tobacco consumption was not associated with prostate cancer $(\mathrm{OR}=1.001, \mathrm{P}=$ 0.996). The same results have been found in the Western and Eastern populations of Algeria [31-32].

However, age is among the strongest prostate cancer risk factors, more than $80 \%$ of prostate cancer is detected in men who are 65 years or older [2]. Actually, it was shown that $42 \%$ of 50 years old men have already developed microscopic evidence of this disease [33]. Our results reveal that age hasinfluence on the development ofprostate cancer(OR $=1.178, P=0.00)$.

Furthermore, in our study, the family history is an independent risk factor ofPCa (OR $=2.53, P=0.009)$.

Several studies reported an increased PCa risk with a positive family history in different populations [34, 35]. Diverse meta-analyses have found that there was a 2-3-fold increased risk of prostate cancer in men who have first-degree family members affected and the risk was slightly lower among those with a second-degree family member.In addition, men can be vulnerable to prostate cancer at an early age in case of having many family members affected $[36,37]$. Moreover, our results are similar to those of Western and Eastern populations of Algeria [31,38]. Due to the significance of these findings, it goes without saying that an earlier diagnosis is essential, especially for men with a higher degree of prostate cancer risk.

\section{Conclusion}

the present study reveals no association between the two genetic polymorphisms of MTHFR enzyme and prostate cancer risk in the North-Center of Algeria population. In addition, folate, homocysteine, vitamin B12 and tobacco are not risk factors for prostate cancer I our population. On the other hand, age and family history play a significant role in the development of PCa. However, it is vital to state that further additional studies with a larger sample size are required for the confirmation of our finding.

\section{Abbreviations}


MTHFR Methylenetetrahydrofolatereductase

PCa Prostate cancer

5,10-methylene THF 5,10-methylenetetrahydrofolate

dTMP desoxythymidinemonophosphate

tHcy total homocysteine

\section{Declarations}

\section{Funding}

The authors declare no funds, grants, or other support were received during the preparation of this manuscript.

\section{Conflict of interest}

The authors declare that they have no competing interests.

\section{Ethical approval}

The institutional ethical committee approved this study.

\section{Acknowledgments}

We wish to thank all participants for their contribution in this work. We also would like to extend our gratitude and appreciation to Professor RedaDjidjik, Professor GhoutiKacimi, Doctor AsmahSaida Merad, Doctor Mohamed El-HadiCherifi, Doctor OuniKhawla and all personnel at the Department of Urology, for their help in carrying out this work.

\section{Author Contributions}

Authors' contributions Design of experiments by RM and MK. Analysis of data by RM and MK. First draft of manuscript by RM, and subsequent drafting by RM, MK, and AC. All authors read and approved the final manuscript.

\section{References}

1. Sung H, Ferlay J, Siegel RL, Laversanne M, Soerjomataram I,et al (2021) Global cancer statistics 2020: GLOBOCAN estimates of incidence and mortality worldwide for 36 cancers in 185 countries. CA. a cancer journal for clinicians 71:209-49. https://doi.org/10.3322/caac.21660

2. Crawford ED (2003) Epidemiology of prostate cancer 62:3-12. http://doiorg/10.1016/j.urology.2003.10-013. 
3. Van den Broeck T, Joniau S, Clinckemalie L, Helsen C, Prekovic S,et al (2014) The role of single nucleotide polymorphisms in predicting prostate cancer risk and therapeutic decision making. BioMed research international. 16 pages. http://dx.doi.org/10.1155/2014/627510

4. Frosst $P$, Blom H, Milos R, Goyette P, Sheppard CA, et al (1995) A candidate genetic risk factor for vascular disease: a common mutation in methylenetetrahydrofolate reductase. Nature genetics 10:111-3. http://doi-org/10.1038/ng0595-111

5. Friso S, Choi S-W (2005) Gene-nutrient interactions in one-carbon metabolism. Current drug metabolism 6:37-46. http://doi-org/10.2174/1389200052997339

6. Jones PA, Baylin SB (2002) The fundamental role of epigenetic events in cancer. Nature reviews genetics 3:415-428. https://doi.org/10.1038/nrg816

7. Saeedi S, Owji A-A, Ansari M, Ghafarpour M, Ebrahimi A, et al (2015) MTHFR Gene polymorphisms and susceptibility to Migraine Attacks. Archives of Medical Laboratory Sciences 1(2). Arch Med Lab Sci. 2015;1(2):61-6. https://doi.org/10.22037/amls.v1i2.10290

8. Chen P, Li W, Wang J, Jiang Y, Wu P, et al (2015) Association between MTHFR gene polymorphisms (C677T, A1298C) and genetic susceptibility to prostate cancer: a meta-analysis. Genetics and molecular research 14:19191-202. https://doi.org/10.4238/2015.December.29.29

9. Jackson MD, Tulloch-Reid MK, McFarlane-Anderson N, Watson A, Seers V, et al (2013) Complex interaction between serum folate levels and genetic polymorphisms in folate pathway genes: biomarkers of prostate cancer aggressiveness. Genes \& nutrition 8:199-207. http://doiorg/10.1007/s12263-012-0321-7

10. López-Cortés A, Jaramillo-Koupermann G, Muñoz MJ, Cabrera A, Echeverría C, et al (2013) Genetic polymorphisms in MTHFR (C677T, A1298C), MTR (A2756G) and MTRR (A66G) genes associated with pathological characteristics of prostate cancer in the Ecuadorian population. The American journal of the medical sciences 346:447-54. http://doi-org/10.1097/MAJ.0b013e3182882578.

11. Collin SM, Metcalfe C, Zuccolo L, Lewis SJ, Chen L, et al (2009) Association of folate-pathway gene polymorphisms with the risk of prostate cancer: a population-based nested case-control study, systematic review, and meta-analysis. Cancer Epidemiology and Prevention Biomarkers 18:2528-39. https://doi.org/10.1158/1055-9965.EPI-09-0223

12. Miller S, Dykes D, Polesky H (1988) A simple salting out procedure for extracting DNA from human nucleated cells. Nucleic acids research 16:1215. http://doi-org/10.1093/nar/16.3.1215

13. Selhub J (2002) Folate, vitamin B12 and vitamin B6 and one carbon metabolism. The journal of nutrition, health \& aging 6:39-42. PMID: 11813080

14. Bistulfi G, VanDette E, Matsui S-I, Smiraglia DJ (2010) Mild folate deficiency induces genetic and epigenetic instability and phenotype changes in prostate cancer cells. BMC biology 8:6. http://doiorg/ 10.1186/1741-7007-8-6.

15. Collin SM, Metcalfe C, Refsum H, Lewis SJ, Zuccolo L, et al (2010) Circulating folate, vitamin B12, homocysteine, vitamin B12 transport proteins, and risk of prostate cancer: a case-control study, 
systematic review, and meta-analysis. Cancer Epidemiology and Prevention Biomarkers 19:1632-42. http://doi-org /10.1158/1055-9965.EPI-10-0180.

16. Zhang D, Wen X, Wu W, Guo Y, Cui W (2015) Elevated homocysteine level and folate deficiency associated with increased overall risk of carcinogenesis: meta-analysis of 83 case-control studies involving 35,758 individuals. PloS one 10:e0123423. http://doi-org/10.1371/journal.pone.0123423.

17. Collin SM (2013) Folate and B12 in prostate cancer. Advances in clinical chemistry 60:1-63. http://doi-org /10.1016/b978-0-12-407681-5.00001-5.

18. Weinstein SJ, Hartman TJ, Stolzenberg-Solomon R, Pietinen P, Barrett MJ, et al (2003) Null association between prostate cancer and serum folate, vitamin B6, vitamin B12, and homocysteine. Cancer Epidemiology and Prevention Biomarkers 12:1271-2. PMID: 14652294.

19. Beilby J, Ambrosini G, Rossi E, De Klerk N, Musk A (2010) Serum levels of folate, lycopene, $\beta$ carotene, retinol and vitamin $\mathrm{E}$ and prostate cancer risk. European journal of clinical nutrition 64:1235. http://doi-org/10.1038/ejcn.2010.124.

20. Abedinzadeh M, Zare-Shehneh M, Neamatzadeh H, Abedinzadeh M, Karami H (2015) Association between MTHFR C677T Polymorphism and Risk of Prostate Cancer: Evidence from 22 Studies with 10,832 Cases and 11,993 Controls. Asian Pacific Journal of Cancer Prevention 16:4525-30. http://doi-org/10.7314/apjcp.2015.16.11.4525.

21. Li X, Xu J (2012) MTHFR polymorphism and the risk of prostate cancer: a meta-analysis of casecontrol studies. Prostate cancer and prostatic diseases 15:244. http://doi-org/10.1038/pcan.2012.5

22. Yadav U, Kumar P, Rai V (2016) Role of MTHFR A1298C gene polymorphism in the etiology of prostate cancer: a systematic review and updated meta-analysis. Egyptian Journal of Medical Human Genetics 17:141-8. https://doi.org/10.1016/j.ejmhg.2015.06.005

23. Safarinejad MR, Shafiei N, Safarinejad S (2010) Relationship between three polymorphisms of methylenetetrahydrofolate reductase (MTHFR C677T, A1298C, and G1793A) gene and risk of prostate cancer: a case-control study. The Prostate 70:1645-57. http://doi-org/10.1002/pros.21200.

24. Marchal C, Redondo M, Reyes-Engel A, Perea-Milla E, Gaitan M, et al (2008) Association between polymorphisms of folate-metabolizing enzymes and risk of prostate cancer. European Journal of Surgical Oncology (EJSO) 34:805-10. http://doi-org/10.1016/j.ejso.2007.09.008.

25. Guo S, Jiang X, Chen X, Chen L, Li X, et al (2015) The protective effect of methylenetetrahydrofolate reductase $\mathrm{C677T}$ polymorphism against prostate cancer risk: Evidence from 23 case-control studies. Gene 565:90-5. http://doi-org/10.1016/j.gene.2015.03.067.

26. Cicek MS, Nock NL, Li L, Conti DV, Casey G, et al (2004) Relationship between methylenetetrahydrofolate reductase $\mathrm{C} 677 \mathrm{~T}$ and $\mathrm{A} 1298 \mathrm{C}$ genotypes and haplotypes and prostate cancer risk and aggressiveness. Cancer Epidemiology and Prevention Biomarkers 13:1331-6. http://doi-org/ 10.3322/caac.20041.

27. Fontham ET, Thun MJ, Ward E, Balch AJ, Delancey JOL, Samet JM (2009) American Cancer Society perspectives on environmental factors and cancer. CA: a cancer journal for clinicians 59:343-51. http://doi-org/10.3322/caac.20041. 
28. Hecht SS (2006) Cigarette smoking: cancer risks, carcinogens, and mechanisms. Langenbeck's archives of surgery 391:603-13. http://doi-org/10.1007/s00423-006-0111-z.

29. Shiels MS, Rohrmann S, Menke A, Selvin E, Crespo CJ, et al (2009) Association of cigarette smoking, alcohol consumption, and physical activity with sex steroid hormone levels in US men. Cancer Causes \& Control 20:877-86. http://doi-org/10.1007/s10552-009-9318-y.

30. Hickey K, Do K-A, Green A (2001) Smoking and prostate cancer. Epidemiologic reviews 23:115-25. http://doi-org//10.1093/oxfordjournals.epirev.a000776.

31. Berroukche A, Bendahmane M, Kandouci BA (2012) Association of diet with the risk of prostate cancer in Western Algeria. Oncologie 14:674-8. http://doi-org/10.1007/s10269-012-2227-9

32. Benabdelkrim M, Djeffal O, Berredjem H (2018) GSTM1 and GSTT1 Polymorphisms and Susceptibility to Prostate Cancer: A Case-Control Study of the Algerian Population. Asian Pacific journal of cancer prevention: APJCP 19:2853-2858. http://doi-org/ 10.22034/APJCP.2018.19.10.2853.

33. Frankel S, Smith GD, Donovan J, Neal D (2003) Screening for prostate cancer. The Lancet 361:11228. http://doi-org/10.1016/S0140-6736(03)12890-5.

34. Cerhan JR, Parker AS, Putnam SD, Chiu BC, Lynch CF, et al (1999) Family history and prostate cancer risk in a population-based cohort of lowa men. Cancer Epidemiology and Prevention Biomarkers 8:53-60. PMID: 9950240.

35. Muller RL, Faria EF, Carvalhal GF, Reis RB, Mauad EC, et al (2013) Association between family history of prostate cancer and positive biopsies in a Brazilian screening program. World journal of urology 31:1273-8. http://doi-org/10.1007/s00345-012-0904-3.

36. Watkins Bruner D, Moore D, Parlanti A, Dorgan J, Engstrom P (2003) Relative risk of prostate cancer for men with affected relatives: systematic review and meta-analysis. International journal of cancer 107:797-803. http://doi-org/10.1002/ijc.11466.

37. Lichtenstein P, Holm NV, Verkasalo PK, lliadou A, Kaprio J, et al (2000) Environmental and heritable factors in the causation of cancer-analyses of cohorts of twins from Sweden, Denmark, and Finland. New England journal of medicine 343:78-85. http://doiorg/10.1056/NEJM200007133430201.

38. Lassed S, Deus CM, Lourenço N, Dahdouh A, Rizvanov AA, et al (2016) Diet, lifestyles, family history, and prostate cancer incidence in an east Algerian patient group. BioMed research international 2016: 9 pages. http://doi-org/10.1155/2016/5730569 